\title{
A Seed-Transmitted Strain of Cucumber Mosaic Virus Isolated from Bean ${ }^{1}$
}

\author{
J. P. Meiners, H. E. Waterworth, F. F. Smith, R. Alconero, and \\ R. H. Lawson ${ }^{2}$
}

\begin{abstract}
Bean leaves with symptoms similar to those caused by bean common mosaic virus (BCMV) were obtained from a plant grown from seed of a plant introduction line growing in Puerto Rico. Differential seed transmission in two bean cultivars (Stringless Green Refugee and Topcrop) inoculated with leaf extracts revealed that the plant was infected with BCMV and cucumber mosaic virus (CMV), designated the PR strain. CMV-PR produced two types of symptoms on beans: mild vein banding on certain cultivars, or top necrosis on others. Host range included 8 genera and 12 species of legumes and 16 species of non-legumes. Physical properties are similar to major strains of CMV. Purified CMV-PR reacted serologically with CMV-C and CMV-S antisera in gel diffusion tests. Virions measured 25 to $27 \mathrm{~nm}$. CMV-PR was transmitted by Myzus persicae to bean and cowpea, and in seed harvested from infected bean and cowpea plants. Survival of the virus in bean and cowpea seed stored for 6 months and 1 year, respectively, enhances the possibility of wide geographic distribution through movement of infected seed.
\end{abstract}

\section{INTRODUCTION}

In the summer of 1970 , leaves were collected in Puerto Rico from a bean (Phaseolus vulgaris L.) introduction (P.I. 150957) showing mosaic symptoms similar to those caused by bean common mosaic virus (BCMV). Fifteen bean cultivars commonly used as differential hosts (1) for strains of BCMV were mechanically inoculated with crude sap from the infected bean. Symptoms were produced on all cultivars. Seed harvested from infected plants of Stringless Green Refugee, a cultivar susceptible to BCMV, produced several plants infected with a previously undescribed strain of BCMV (2). Seed harvested from infected plants of Topcrop, a cultivar normally immune to BCMV, produced one plant with symptoms atypical of those caused by BCMV or any other virus known to infect beans. Studies were initiated to identify and characterize the causal agent, which proved to be a strain of cucumber mosaic virus (CMV) designated as CMV-PR (9).

${ }^{1}$ Manuscript submitted to Editorial Board March 26, 1976.

${ }^{2}$ First and fifth authors, Research Plant Pathologists, and third author, Research Entomologist (Retired), ARS, USDA, Beltsville, Maryland 20705; second author, Research Plant Pathologist, ARS, USDA, U.S. Plant Introduction Station, Glenn Dale, Maryland 20769; fourth author, Research Plant Pathologist, ARS, USDA, Mayagüez Institute of Tropical Agriculture, Mayagüez, P.R. The technical assistance of A. G. Santiago, C. W. Rogers, S. S. Hearon, and W. R. Povish is gratefully acknowledged. We are grateful to Dr. Julio Bird, University of Puerto Rico, for providing a culture of bean vein-banding mosaic virus for comparative purposes. 
The first report of CMV occurring naturally in beans was by Whipple and Walker (13) who found it in nursery plantings. Subsequently, Kaiser et al. (7) reported CMV occurring naturally in beans in Iran. Recently, Bird et al. (4) reported a mosaic occurring in beans in Puerto Rico caused by a virus which they named bean vein-banding mosaic virus (BVBMV) and which is serologically related to CMV. A strain of CMV that is seed-borne in beans was recently described by Bos and Maat (5).

\section{MATERIALS AND METHODS}

CMV-PR-infected Topcrop bean plants grown from seed-borne infection was the source of virus for the studies. Host range, in vitro properties, electron microscopy, and serological comparisons of CMV-PR were made with BVBMV (4).

Antisera for the following viruses were obtained from the American Type Culture Collection: southern bean mosaic, bean pod mottle, carnation ringspot, peanut stunt, broad bean mottle, cowpea mosaic, and cucumber mosaic virus strains $\mathrm{C}(6,10)$ and $\mathrm{S}$ as PV-AS $2,9,22,62,83$, 84,88 , and 60 , respectively. Colleagues kindly supplied antisera to the following viruses: bean rugose mosaic (Gamez); red clover mosaic (Valenta); Chicory yellow mottle (Quacquarelli); cowpea chlorotic mottle (Kuhn); Echtes Ackerbohnemosaik (Paul); raspberry ringspot (Maat); squash mosaic (Lee); and tomato bushy stunt (Wetter). Other antisera were produced in our laboratory.

CMV-PR for the host range and physical property studies was obtained from bean cultivars or Nicotiana glutinosa L. Inoculated plants not showing distinct symptoms were back-indexed on Columbia Pinto bean, Thailen mung bean, and/or Chenopodium quinoa Willd. (table 1).

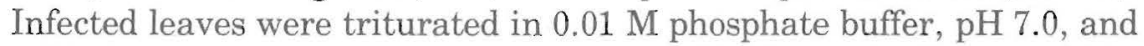
rubbed onto leaves of test plants dusted with 320 mesh silicon carbide.

Thermal inactivation, dilution endpoint, and aging in vitro were determined, using sap extracted in $0.01 \mathrm{M}$ neutral phosphate buffer ( 5 $\mathrm{ml} / \mathrm{g}$ of leaf tissue) from systematically infected leaves of Columbia Pinto 1 week following inoculation. For each property test, 10 plants each of Columbia Pinto and Chenopodium quinoa were inoculated. Infection was indicated by chlorotic local lesions (C. quinoa) and veinal necrosis (Columbia Pinto).

CMV-PR and, for comparative purposes, BVBMV (4) were purified from fresh bean or Nicotiana tabacum cv (Samsun) tissue 2 weeks after inoculation. Leaves were blended in two volumes of $0.5 \mathrm{M}$ citrate buffer, $\mathrm{pH} 7.5$, containing $0.1 \%$ thioglycolic acid or $0.02 \mathrm{M}$ 2-mercaptoethanol. Juice was clarified by adding chloroform to the tissue while blending to $20 \%$ of the volume of buffer and centrifuging the slurry at 10,000 g for 12 min. The clear yellow supernatant was then centrifuged at $100,000 \mathrm{~g}$ for 
$1.2 \mathrm{~h}$. High speed pellets were resuspended in $0.05 \mathrm{M}$ neutral sodium citrate buffer containing $2 \%$ Triton-X-100 ${ }^{3}$ detergent which was effective in degrading green materials (8). Resuspended and combined high speed pellets were centrifuged at $8,000 \mathrm{~g}$ to remove traces of green material. Aliquots of this opalescent preparation were layered onto sucrose gradients in $0.02 \mathrm{M}$ citrate or borate, centrifuged $2 \mathrm{~h}$ and analyzed as previously described (12). Virus was reconcentrated by ultracentrifugation.

Purified CMV-PR suspended in 0.05 M neutral sodium citrate buffer was diluted 1:1 with distilled water and placed onto a Formvar coated grid. An equal volume of PTA, adjusted to $\mathrm{pH} 7.0$ with $\mathrm{KOH}$, was dropped onto the virus sample, mixed with a pipette and dried with filter paper. Samples were also mixed 1:1 with a $4 \%$ neutral buffered solution of glutaraldehyde. The mixture was immediately stained with KPTA using the same procedure. Purified BVBMV also was compared in KPTA stained preparations unfixed and in glutaraldehyde using the procedure described above.

Two rabbits were immunized with 2 to $3 \mathrm{mg}$ of the partially purified CMV-PR and bled as previously described (12). Double diffusion serological tests were performed using concentrated preparations of the virus in $0.75 \%$ Ion Agar No. 2 in water containing $0.02 \%$ sodium azide preservative with well spacings of $5 \mathrm{~mm}$.

For insect transmission tests, green peach aphids, Myzus persicae (Sulzer) were reared on healthy radish or spinach seedlings. Adult apterous females were starved for $2 \mathrm{~h}$, then placed on infected leaves. After feeding for $10 \mathrm{~min}$, the aphids were transferred by brush or leaf pieces bearing aphids and placed on pieces of paper near the growing point of each test plant. The aphids usually moved within 10 to $15 \mathrm{~min}$ to the test plants. In the tests for retention of the virus, aphids that had fed for $10 \mathrm{~min}$ on infected leaves were brushed into stendor dishes without food. At 10-min intervals up to 70 min, groups of 10 to 25 aphids were transferred by brush to a series of plants. Aphids remaining on plants after $24 \mathrm{~h}$ were destroyed by dipping the plants in nicotine sulfate solution. Virus transmission by aphids was tested by back-indexing through mechanical inoculation to Columbia Pinto bean test plants.

To test for seed transmission, mature seed was harvested from infected bean plants and planted immediately, or after a period of storage at room temperature, in 4-inch pots in the greenhouse. Resulting plants showing symptoms were assayed to confirm infection.

${ }^{3}$ Trade names are used in this publication solely for the purpose of providing specific information. Mention of a trade name does not constitute a guarantee or warranty of equipment or materials by the Agricultural Experiment Station of the University of Puerto Rico or an endorsement over other equipment or materials not mentioned. 
RESULTS

\section{HOST RANGE}

All of the 34 bean cultivars mechanically inoculated with the virus became systemically infected (table 1). On 30 of the 34 cultivars, the most prominent symptom was mild vein banding only (fig. 1-B). Occasionally, certain cultivars exhibited vein clearing, or mosaic, but the virus had no effect on leaf size or shape and caused little or no stunting of the plants. Conversely, symptoms produced on four related cultivars of dry beans (Pinto US No. 5, Pinto US No. 14, Columbia Pinto, and Great Northern No. 1140) were very prominent. Necrotic lesions on the primary leaves were rapidly followed by vein necrosis and spread of the necrosis into the petioles, stem, and growing points that resulted in death of the plants. All infected plants of Pintos 5 and 14, and Great Northern 1140 were killed, whereas approximately $72 \%$ (285/398) of plants of Columbia Pinto succumbed. The remaining $28 \%$ showed the mild symptoms exhibited by most of the cultivars. Subsequently, inoculations of single plant selections of Columbia Pinto indicated a mechanical mixture of genotypes homozygous for each of the two syndromes.

With cv. Topcrop, infection resulting from seed-borne virus, and rarely from mechanical inoculation, was accompanied by severe symptoms (fig. 2) consisting of a narrowing and cupping of the leaves, rugosity of the leaf surface, and stunting of the plant.

Host range and symptoms of BVBMV provided by Bird (4) were compared with CMV-PR on selected species. Symptoms caused by BVBMV were exactly as described by Bird et al. (4) on all cultivars of beans inoculated mechanically, and were much more severe than those produced by CMV-PR (fig. 1). However, BVBMV did not produce local lesions or top necrosis in Pintos 5 and 14, Columbia Pinto, or Great Northern 1140, as did CMV-PR. In comparative studies at Beltsville, the host range of the two viruses on the selected hosts listed in table 1 differed only in reaction of Lathyrus sativus L. (immune to BVBMV), Gomphrena globosa L., and Lens culinaris Medic. (latent systemic infection by BVBMV).

\section{STABILITY IN VITRO PROPERTIES}

CMV-PR was infectious after $5 \mathrm{~d}$, but not after $6 \mathrm{~d}$; in vitro after heating for $10 \mathrm{~min}$ at $70 \mathrm{C}$, but not at $75 \mathrm{C}$; and after diluting expressed sap to $10^{-3}$, but not to $10^{-4}$.

\section{PURIFICATION AND ELECTRON MICROSCOPY}

Both strains sedimented in sucrose gradient to form a single visible band $2.5 \mathrm{~cm}$ below the meniscus; however, when fractioned and ana- 
TABLE 1.-Reaction of selected plant species and cultivars to mechanical inoculation with cucumber mosaic virus-Puerto Rico strain

\begin{tabular}{|c|c|}
\hline Genus, species, cultivar ${ }^{1}$ & Reaction ${ }^{2}$ \\
\hline \multicolumn{2}{|l|}{ Legumes: } \\
\hline Canavalia ensiformis (L.) DC. & Lat. \\
\hline Dolichos uniflorus Lam. & LLN \\
\hline Lathyrus sativus L. & Lat. \\
\hline \multicolumn{2}{|l|}{ Macroptilium atropurpureum (DC.) Urb. } \\
\hline Siratro & Lat. \\
\hline M. lathyroides L. & $\mathrm{M}, \mathrm{S}, \mathrm{VC}$ \\
\hline \multicolumn{2}{|l|}{ Phaseolus coccineus L. Achievement, } \\
\hline Harrisons Tenderpod, Kelvedon Marvel & VB \\
\hline \multicolumn{2}{|l|}{ P. lunatus L. Dixie Butter Pea, } \\
\hline $\begin{array}{l}\text { Fordhook 242, Henderson Bush, } \\
\text { Jackson Wonder }\end{array}$ & M \\
\hline$P$. vulgaris L. 34 cultivars & VB, VC, M, TN \\
\hline Pisum sativum L. Alaska, Perfected Wales & Lat. \\
\hline Vicia faba L. & Lat. \\
\hline \multicolumn{2}{|l|}{ Vigna radiata (L.) Wilczek } \\
\hline Berken, Moren, Thailen & LLN \\
\hline \multicolumn{2}{|l|}{ V. unguiculata (L.) Walp. } \\
\hline Blackeye no. 5, Early Ramshorn, Yardlong & M \\
\hline Suneta & M, LLN \\
\hline \multicolumn{2}{|l|}{ Non-legumes: } \\
\hline Capsicum annuum L. Cayenne & LLN \\
\hline Chenopodium amaranticolor Coste \& Reyn. & LLC \\
\hline C. capitatum (L.) Aschers. & LLC \\
\hline C. quinoa Willd. & LLC \\
\hline $\begin{array}{l}\text { Cucumis sativus L. Long Green, } \\
\text { Pixie, Lemon, Palomar }\end{array}$ & VC \\
\hline Gomphrena globosa L. & $\mathrm{M}, \mathrm{LC}, \mathrm{VN}$ \\
\hline Nicotiana alata Link \& Otto & $\mathrm{M}$ \\
\hline N. arentsii Goodsp. & Lat. \\
\hline N. clevelandii Gray & S \\
\hline N. debneyi Domin. & LLC \\
\hline N. glutinosa L. & $\mathrm{M}, \mathrm{LC}$ \\
\hline N. langsdorfii Schrank & M \\
\hline N. longiflora Cav. & Lat. \\
\hline N. rustica L. & M \\
\hline N. tabacum L. Samsun, Burley, H 423 & $\mathrm{M}$ \\
\hline Zinnia elegans Jacq. & LLC \\
\hline
\end{tabular}

${ }^{1}$ Inoculation of the following species and cultivars resulted in no infection: LegumesArachis hypogaea L. Tifspan; Cajanus cajan Millsp.; Cicer arietinum L.; Crotalaria juncea L.; Dolichos lablab L.; Glycine max Merr. Biloxi, Clark, Delmar, Scott; Lens culinaris Medic.; Medicago sativa L.; Phaseolus acutifolius Gray; Pueraria phaseoloides (Roxb.) Benth.; Trifolium incarnatum L.; T. pratense L. Chesapeake; Vicia sativa L. Non-legumes-Cucumis sativus L. Straight Eight, Marketeer, Ashley, China, National Pickling, Ohio M 717, Spartan Champ; Datura stramonium L.; Helianthus annuus L.; Lycopersicon esculentum Mill. Bonny Best; Nicotiana acuminata (Grah.) Hook.; N. affinis Moore; $N$. acuminata var. multiflora Reiche; $N$. bigelovii Watts.; $N$. excelsior Black; Physalis floridana Rydb.; Spinacia oleracea L.

${ }^{2}$ Lat. = latent systemic infection; $\mathrm{LC}=$ leaf curling; $\mathrm{M}=$ mosaic; $\mathrm{S}=$ stunting; $\mathrm{TN}=$ top necrosis; $\mathrm{VB}=$ vein banding; $\mathrm{VC}=$ vein clearing; $\mathrm{LLC}=$ chlorotic local lesions; $\mathrm{LLN}$ $=$ necrotic local lesions. 

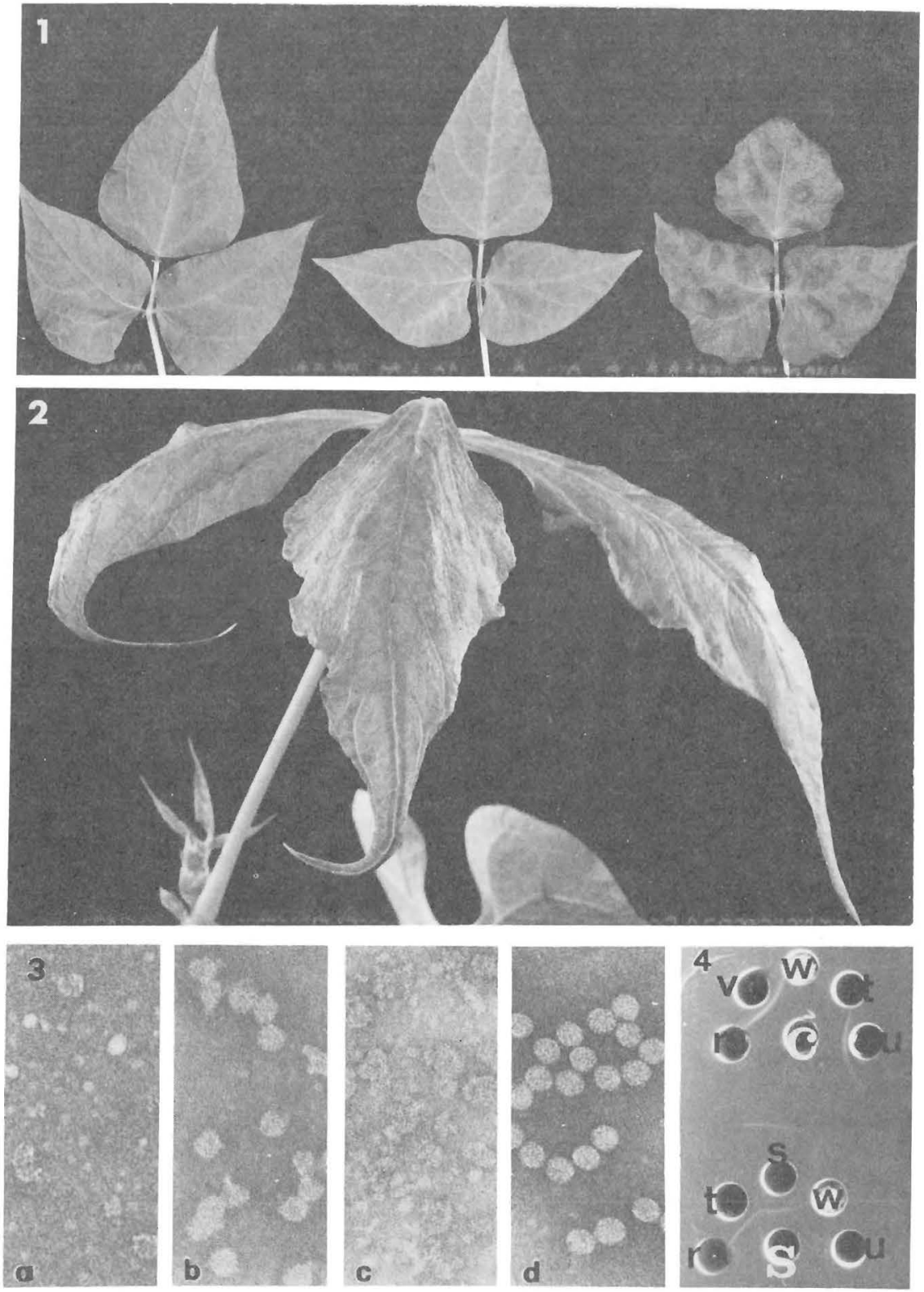

FrG. 1. - Symptoms produced by strains of cucumber mosaic virus (CMV) on Ouray bean. (Left) Uninoculated; (center) CMV - Puerto Rico strain (PR); (right) Bean VeinBanding mosaic virus (BVBMV).

Frg. 2.-Symptoms of cucumber mosaic, Puerto Rico strain (CMV-PR), in Topcrop bean from seed-borne infection.

Fig. 3.-(A-D) Electronmicrographs of CMV virions. A) CMV-PR not stabilized in glutaraldehyde; B) CMV-PR stabilized in glutaraldehvde; C) BVBMV not stabilized in glutaraldehyde; D) BVBMV stabilized in glutaraldehyde. 115,000x.

Fig. 4. - Serological relationships of CMV strains. Center wells contain antisera to $\mathrm{CMV}$; top) strain $\mathrm{C}$, and bottom) strain $\mathrm{S}$. Outside wells contain $(\mathrm{r}-\mathrm{v})$ partially purified virus: r) peanut stunt virus, s) CMV-S, t) CMV-BVBMV, u) CMV-PR, v) CMV-C, and w) virus-free plant sap. 
lyzed with ultraviolet light, two distinct adjacent peaks were observed with about $10 \%$ of the virus in the more rapidly sedimenting fraction. A reddish-brown nonvirus band $1.5 \mathrm{~cm}$ below the meniscus was also observed. Yields of purified virus were about 8 and $15 \mathrm{mg} / 100 \mathrm{~g}$ tissue of CMV-PR and BVBMV, respectively, using an assumed extinction coefficient of $\mathrm{E}_{260}^{0.01}=50.0$. CMV-PR settled out in the presence of 0.02 to $0.1 \mathrm{M}$ ethylenediaminetetraacetic acid (EDTA). Only a few virions were recognized in purified CMV-PR preparations. Most of the virions were disrupted (fig. 3 -a). The addition of glutaraldehyde partially stabilized the virions. Many of the particles appeared partially degraded and showed an irregular profile with some distortion. Some particles were packed in small clusters, suggesting that some aggregation occurred (fig. 3-b). The virus particles were 25 to $27 \mathrm{~nm}$ in diameter.

In unfixed BVBMV there were some recognizable virions, but many of the particles were partially degraded (fig. 3 -c). In contrast, preparations fixed in a final concentration of $2 \%$ glutaraldehyde were well preserved and showed no evidence of degradation (fig. 3-d). The particles ranged in size from 24 to $27 \mathrm{~nm}$.

\section{SEROLOGY}

CMV-PR regularly reacted with a heavy curved band with CMV-C antiserum (6) and in two of six tests it also produced a weak band with CMV-S antiserum (fig. 4). CMV-BVBMV reacted only with CMV-S antiserum. These strains did not react with antisera to other members of the comovirus group, i.e. tomato aspermy or peanut stunt viruses, nor with any of the other antisera tested. Titer of the antiserum to CMV-PR collected from each of two rabbits did not exceed 1:16, while that produced with the CMV-S antigen exceeded 1:256 following a similar injection scheme.

\section{APHID TRANSMISSION}

In 15 tests, Myzus persicae transmitted CMV-PR to 56\% of the test plants of Columbia Pinto and Blackeye No. 5 when transferred by the leaf piece method. When aphids were transferred by brush from infected leaf pieces, $21 \%$ of the bean plants and $46 \%$ of the cowpea plants were infected. Aphids evidently were injured by the sharp pubescence on the beans in spite of care exercised in placing them on the plants.

In eight tests for virus retention, the aphids infected cowpea plants up to $30 \mathrm{~min}$ and bean plants up to $40 \mathrm{~min}$ after removal from infected source leaves.

Groups of 25 aphids per test resulted in higher transmission than did 
10 aphids. Young fully expanded primary leaves were critically necessary for infection. No infection occurred in plants with expanding trifoliate leaves. Infection occurred in cowpea plants, but not in bean plants, when primary leaves were still furled after emergence from the seed coat.

Symptoms on both Columbia Pinto and Blackeye No. 5 produced by inoculation with aphids were idenitcal to those produced by mechanical inoculation.

\section{SEED TRANSMISSION}

CMV-PR was transmitted through 1.5\% (6/397) of seed of three cultivars of beans. In two experiments it was transmitted through $0.4 \%$ (1/269) and 18\% (6/34) of seed of Blackeye No. 5 cowpea produced on infected plants. Up to $9 \%$ seed transmission occurred in seed from individual bean plants and up to $30 \%$ in seed from individual cowpea plants. In bean, symptoms caused by seed-borne virus were different and more severe than those resulting from mechanical inoculation (fig. 3). Bird et al. (4) reported BVBMV not to be seed-borne. The results of the experiments with BVBMV herein reported, indicated $0.39 \%(1 / 399)$ transmission through seed harvested from plants of several cultivars infected with BVBMV.

\section{DISCUSSION}

CMV-PR was identified as a strain of CMV on the basis of host range, serology, physical properties, and electron microscopy.

A comparison of CMV-PR with BVBMV, another strain of CMV from bean (4), indicated major differences in symptoms (fig. 1) and properties related to stability, structure, and seed transmission. Results from electron microscopy show that CMV-PR is less stable than BVBMV. Necessity to transfer CMV-PR more often than BVBMV to maintain a viable culture confirms this lack of stability. Moreover, physical properties of BVBMV as reported by Bird et al. (4) differed greatly from CMVPR, but these could be due to different assay hosts or other varying experimental conditions.

A comparison of the characteristics of CMV-PR with strains of CMV other than BVBMV reported in the literature reveals several similarities and differences $(5,6,13)$.

Whipple and Walker (13) report CMV to produce necrosis of bean plants in the field, but mild symptoms in greenhouse inoculation, 
suggesting a situation similar to that of CMV-PR where type of symptom is related to particular cultivars. Fulton (6) reported that strain $\mathrm{C}$ of CMV, to which CMV-PR is closely related serologically, caused death and stem necrosis of bean. However, symptoms produced by strain $\mathrm{C}$ on other hosts differed greatly from those produced by CMV-PR. The strain of CMV from bean investigated by Bos and Maat (5) produces symptoms on bean similar to those produced by the BVBMV strain, but different from the symptoms produced by CMV-PR. Conversely, percent seed transmission in beans with the Bos and Maat strain of CMV was similar to CMV-PR and differed greatly from BVBMV which is scarcely seedtransmitted.

Host ranges reported for those strains occurring naturally on beans $(4,5,13)$ were compared to those of CMV-PR. In the case of legumes, host ranges of the four strains were similar. Notable exceptions include failure of the Bos and Maat strain to infect pea, BVBMV to infect mung bean, and that of Whipple and Walker to infect Vicia faba L. The most striking differences with non-legumes was the failure of CMV-PR to infect Datura stramonium L., tomato, and spinach.

CMV is stabilized by the addition of $0.005 \mathrm{M}$ EDTA, but many virus particles were disrupted in the presence of EDTA when the preparation was stained with $2 \%$ potassium phosphotungstate (KPTA) (11). Particles of BVBMV are very stable in KPTA when previously fixed in glutaraldehyde. In contrast, extensive breakdown was observed in unfixed CMV-PR, and the virus particles showed distortion, breakdown, and some aggregation even when stabilized with glutaraldehyde prior to staining.

CMV has been reported to be seed-borne in pea, yardlong bean, and cowpea (3). Since the studies reported herein were completed, CMV also has been reported to be seed-transmitted in bean (5). Our tests confirm that CMV is seed-borme in cowpea and bean, although strains vary in percentages of seed transmission on specific species and cultivars. Since CMV-PR is transmitted by aphids, a few infected plants probably could result in spread of the disease during the growing season. The fact that CMV-PR survived in bean seed for over $6 \mathrm{mo}$, and in cowpea seed for over a year, implicates seed as a vehicle for dissemination of this virus over wide geographical areas.

The geographical distribution of CMV-PR in Puerto Rico is unknown. However, the fact that two distinct strains have been found in two widely separated locations on the island indicates that leguminous strains of CMV may have been present in Puerto Rico for some time. The host range studies indicate that it could occur in the ubiquitous leguminous species Macroptilium lathyroides. 
CMV-PR appears to be of little economic importance since effects on most cultivars of bean and cowpea are very mild. However, when combined with BCMV infection, symptoms are more severe than those caused by either virus alone, and might result in severe crop loss.

\section{RESUMEN}

Hojas de habichuelas con síntomas parecidos a los del virus del mosaico común de la habichuela (BCMV) se recolectaron de una planta originada de semilla de una línea de habichuela introducida en Puerto Rico. La transmisión a dos cultivares de habichuelas (Stringless Bean Refugee y Topcrop) inoculados con extracto de las hojas, revelaron que la planta estaba infecta con BCMV y el virus del mosaico del pepinillo (CMV), designado como estirpe PR. La estirpe CMV-PR mostró dos tipos de síntomas: un leve bandeado de las nerviaciones en algunos cultivares y necrosis del ápice en otros. Las plantas hospederas representaban 8 géneros y 12 especies de leguminosas y 16 especies de otras familias. Las propiedades físicas son similares a las de las estirpes corrientes de CMV. La estirpe CMV-PR reaccionó serológicamente con los antisueros de CMV-C y CMV-S en pruebas de difusión en gel. Los viriones midieron de 25 a 27 manómetros. La estirpe CMV-PR fue transmitida a la habichuela y al fríjol por el áfido Myzus persicae y por semilla recolectada de plantas infectas de esas dos especies. La supervivencia del virus en semillas de habichuela y fríjol almacenadas por 6 meses y 1 año, respectivamente, agravan la posibilidad de una amplia diseminación geográfica por medio de semilla infecta.

\section{LITERATURE CITED}

1. Alconero, R., and Meiners, J. P., The effect of environment on the response of bean cultivars to infection by strains of bean common mosaic virus, Phytopathology 64 : $679-82,1974$.

2. - - , and Santiago, A., A new strain of common bean mosaic in Puerto Rico, Phytopathology 62: 667, (Abstr.), 1972.

3. Anderson, C. W., Seed transmission of three viruses in cowpea, Phytopathology 47: 515, (Abstr.), 1957.

4. Bird, J., Sánchez, J., Rodríguez, R. L., Cortés-Monllor, A., and Kaiser, W., A mosaic of beans (Phaseolus vulgaris L.) caused by a strain of common cucumber mosaic virus, J. Agr. Univ. P.R. 58(2): 151-61, 1974.

5. Bos, L., and Maat, D. Z., A strain of cucumber mosaic virus, seed-transmitted in beans, Neth. J. Pl. Path. 80: 113-23, 1974.

6. Fulton, J. P., Studies on strains of cucumber virus 1 from spinach, Phytopathology 40: 729-36, 1950.

7. Kaiser, W. J., Danesh, D., Okhovat, M., and Mossahebi, G. H., Virus diseases of pulse crops in Iran, Bull. Fac. Agr. Univ. Teheran, Karaj, Iran, 111 p., 1972.

8. Lot, H., Marrou, J., Quiot, J. B., and Esvan, C., Contribution à l'étude du virus de la mosaïque du concombre (CMV), Ann. Phytopathology 4: 25-38, 1972.

9. Meiners, J. P., Smith, F. F., Lawson, R. H., Waterworth, H. E., and Alconero, R., A strain of cucumber mosaic virus seed-borne in bean (Phaseolus vulgaris), Proc. Am. Phytopath. Soc. 1:37, (Abstr.), 1974.

10. Scott, H. A., Serological behavior of cucumber mosaic virus (Strain Y) and the virus protein, Virology 34: 79-90, 1968.

11. Tomlinson, J. A., Carter, A. L., Faithfull, E. M., and Webb, M. J. W., Purification 
and serology of the W strain of cucumber mosaic virus, Ann. Appl. Biol. 74: 181-9, 1973.

12. Waterworth, H. E., and Kaper, J. M., Purification and properties of carnation mottle virus and its ribonucleic acid, Phytopathology 62: 959-64, 1972.

13. Whipple, O. C., and Walker, J. C., Strains of cucumber mosaic virus pathogenic on bean and pea, J. Agr. Res. 62: 27-60, 1941. 